\title{
Odpowiedzialność polityczna Rady Ministrów
}

\author{
Aldona Domańska \\ Uniwersytet Łódzki, Wydział Prawa i Administracji \\ Katedra Prawa Konstytucyjnego
}

Odpowiedzialność podmiotów sprawujących władzę należy do podstawowych wymogów współczesnych demokracji. Stanowi cześć demokratycznych mechanizmów sprawowania władzy państwowej ${ }^{1}$.

Współcześnie odpowiedzialność podmiotów piastujących władzę jest gwarancją praworządności. Jest „korelatem władzy, tak iż zakres i rodzaj władzy określają zakres i rodzaj odpowiedzialności”2.

Już Monteskiusz pisał, że „wiekuiste doświadczenie uczy, iż wszelki człowiek, który posiada władzę, skłonny jest jej nadużywać; posuwa się tak daleko, aż napotka granice" ${ }^{3}$. Dlatego tak istotne jest, by państwo wyznaczało granice dopuszczalnych działań organów władzy oraz przejrzysty system egzekwowania odpowiedzialności w przypadku ich przekroczenia. Ponadto należy przyjąć, że dla polityka udział w rządzeniu państwem dla dobra wspólnego stanowi istotę odpowiedzialności ${ }^{4}$. Zaś odpowiedzialność polityków to naturalne następstwo dokonanych przez nich wyborów.

Na gruncie prawa konstytucyjnego wyróżniamy dwa rodzaje odpowiedzialności: polityczną (parlamentarną) i prawną (konstytucyjną). Przedmiotem niniejszego opracowania pozostanie wyłącznie odpowiedzialność polityczna, zawężona podmiotowo do członków Rady Ministrów.

Odpowiedzialność polityczna - jako jedna z form odpowiedzialności organów władzy - jest elementem koniecznym realizacji zasad demokratycznego państwa prawnego oraz podziału władzy; jest komponentem współczesnego pojęcia demokracji oraz instrumentem kontroli władzy. Zdaniem Philippe’a Brauda funkcją odpowiedzialności politycznej jest to, że wyłączone są z jej zakresu podmiotowego inne podmioty uczest-

1 R. Mojak, Status ustrojowy Rady Ministrów, [w:] W. Skrzydło, R. Mojak (red.), Ustrój polityczny Rzeczypospolitej Polskiej w nowej Konstytucji z 2 kwietnia 1997 r., Lublin 1998, s. 69.

2 J. Hudzik, Rozum - wolność - odpowiedzialność. Studium z historii idei w nowożytnej i wspótczesnej myśli filozoficznej, Lublin 2001, s. 299.

3 K. L. Montesquieu, O duchu praw, t. 1, Warszawa 1957, s. 232.

4 J. Hudzik, Rozum..., s. 212-214. 
niczące $\mathrm{w}$ sprawowaniu władzy, w tym przede wszystkim prezydent ${ }^{5}$. Odpowiedzialność tę ponosi zazwyczaj organ prowadzący politykę państwa, czyli rząd i jego członkowie. Uwidacznia się to zwłaszcza w systemie rządów parlamentarnych, w których władza rządu opiera się na zaufaniu większości parlamentarnej.

Niestety, należy zgodzić się z poglądem G. Smitha, że „władza wykonawcza jest odpowiedzialna przed ciałem ustawodawczym, ale ceną za to jest zgoda na kierownictwo sprawowane przez egzekutywę za pośrednictwem systemu partyjnego"6.

Analizując rozwiązania przyjęte przez ustrojodawców współczesnych państw demokratycznych, należy podkreślić, że w systemach parlamentarnych przyjmuje się różne rozwiązania, warianty odpowiedzialności rządu i „o ile odpowiedzialność solidarna stanowi conditio sine qua non modelu parlamentarnego, to odpowiedzialność indywidualna nie ma tak uniwersalnego charakteru"'. Coraz częściej ustrojodawcy państw o parlamentarnym systemie rządów w rozwiązaniach konstytucyjnych rezygnują z odpowiedzialności indywidualnej członków rządu. W doktrynie pojawiają się poglądy, że „współcześnie w państwach demokratycznych [...] indywidualna odpowiedzialność przed parlamentem stanowi rozwiąza-

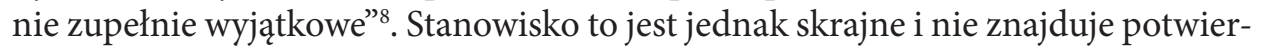
dzenia w obowiązujących rozwiązaniach konstytucyjnych współczesnych państw demokratycznych.

System parlamentarny jest jednak bardzo zróżnicowany, a najbardziej popularny jest model parlamentarny zracjonalizowany, w którym mieści się polski system ustrojowy ${ }^{9}$. Niektórzy przedstawiciele doktryny podnoszą, że status ustrojowy Rady Ministrów zawiera się w koncepcji systemu parlamentarnego zmodyfikowanego, recypującego do systemu parlamentarno-gabinetowego elementy systemu kanclerskiego ${ }^{10}$. Cechą tego systemu jest „dbałość o nieuszczuplenie prawa Sejmu [...] przy jednoczesnym wysiłku do minimalizowania negatywnych skutków politycznego rozbicia jego składu"11.

W polskim modelu podkreśla się, że odpowiedzialność polityczna rządu ma charakter:

1) parlamentarny - ponieważ Rada Ministrów ponosi tę odpowiedzialność przed Sejmem;

2) zracjonalizowany - gdyż dla swej skuteczności wymaga wypełnienia skomplikowanych warunków proceduralnych;

5 Ph. Braud, Rozkosze demokracji, Warszawa 1995, s. 119.

6 G. Smith, Życie polityczne w Europie Zachodniej, Warszawa 1992, s. 161.

7 L. Garlicki, Rada Ministrów: powoływanie - kontrola - odpowiedzialność, [w:] A. Bałaban (red.), Rada Ministrów - organizacja i funkcjonowanie, Kraków 2002, s. 154.

8 W. Sokolewicz, Odpowiedzialność parlamentarna Rzq̨du RP, Warszawa 1993, s. 65.

9 R. Mojak, Parlament a rzqd w ustroju Trzeciej Rzeczypospolitej Polskiej, Lublin 2007, s. 323 i n.

10 R. Mojak, Status ustrojowy Rady Ministrów..., s. 54; B. Dziemidok-Olszewska, Odpowiedzialność głowy państwa i rzq̨du we współczesnych państwach europejskich, Lublin 2012, s. 161.

11 M. Kruk, System rządów w Konstytucji Rzeczypospolitej z 2 kwietnia 1997 r., [w:] W. Skrzydło, R. Mojak (red.), Ustrój polityczny Rzeczypospolitej Polskiej..., s. 49. 
3) ustrojowy - względy natury ustrojowej przesądzają o politycznym charakterze odpowiedzialności parlamentarnej.

Odpowiedzialność parlamentarna rządu jako całości oraz jego poszczególnych członków jest cechą polskiego systemu parlamentarno-gabinetowego ${ }^{12}$. Jest ona egzekwowana za pomocą instytucji wotum nieufności ${ }^{13}$. Oznacza to, że cechą charakterystyczną tego systemu - jak już wcześniej podkreślano - jest to, że władza rządu opiera się na posiadaniu zaufania większości parlamentarnej. To zaufanie decyduje o legitymacji, a w konsekwencji o faktycznej możliwości wykonywania przez rząd kompetencji.

Zgodnie z przepisami Konstytucji RP Rada Ministrów ponosi odpowiedzialność przed Sejmem, a nie przed Senatem ani tym bardziej Prezydentem RP. Uzasadnieniem dla takiej konstrukcji jest realizacja funkcji kontrolnej Sejmu ${ }^{14}$. Jest ona realizowana w procedurze odpowiedzialności:

1) solidarnej - w postaci wyrażenia konstruktywnego wotum nieufności oraz odmówienia wotum zaufania (art. 157 ust. 1 Konstytucji RP) ${ }^{15}$;

2) indywidualnej - w postaci wotum nieufności dla poszczególnych ministrów za sprawy należące do ich kompetencji lub powierzone im przez Prezesa Rady Ministrów (art. 157 ust. 2 Konstytucji RP) ${ }^{16}$.

Pierwsza z nich zgodnie ze swą nazwą ma charakter polityczny, takie też są powody i skutki jej zastosowania. Występuje ona wówczas, gdy między polityką realizowaną przez Radę Ministrów a postulowaną przez większość parlamentarną występuje widoczna rozbieżność stanowisk, gdy większość ta nie aprobuje już polityki rządu. Skutkiem zastosowania tej formy odpowiedzialności jest ustąpienie Rady Ministrów, która podaje się do dymisji - bądź z uwagi na krytykę swego stanowiska, bądź gdy parlament odmawia jej zaufania lub też gdy wyraża jej wotum nieufności ${ }^{17}$.

Powszechnie przyjmuje się, że wotum nieufności to uchwała parlamentu wyrażająca odmowę poparcia dla całego rządu lub jego członka. Jego istota polega na żądaniu przez parlament ustąpienia gabinetu lub ministra, zaś przesłanką uchwalenia jest negatywna ocena prowadzonej przez rząd polityki ${ }^{18}$. Negatywna ocena może obejmować wszystkie dziedziny aktywności rządu bądź tylko jakiś element.

12 E. Zwirzchowski, Kanclerz a rząd federalny, [w:] L. Janicki (red.), Ustrój państwowy Republiki Federalnej Niemiec, Poznań 1986, s. 425, R. Mojak, Parlament a rzq̨d..., s. 543.

13 M. Domagała, Charakter prawny i miejsce Trybunału Konstytucyjnego i Trybunału Stanu w systemie organów państwa, [w:] W. Skrzydło (red.), Ustrój i struktura aparatu państwowego i samorzadu terytorialnego, Warszawa 1997, s. 129.

14 W. Sokolewicz, Odpowiedzialność parlamentarna..., s. 12.

15 Konstytucja Rzeczypospolitej Polskiej z dnia 2 kwietnia 1997 r. uchwalona przez Zgromadzenie Narodowe w dniu 2 kwietnia 1997 r., Dz.U. z 1997 r., nr 78, poz. 483.

16 Ibidem.

17 W. Skrzydło et al., Polskie prawo konstytucyjne, Lublin 2010, s. 346.

18 L. Garlicki, Rada Ministrów..., s. 161; R. Mojak, Parlament a rząd..., s. 557 
Odpowiedzialność solidarna - całej Rady Ministrów przed Sejmem - została wyrażona $w$ postaci konstruktywnego wotum nieufności. Instytucja ta ma charakter sformalizowany i zawiera szereg wymogów zapobiegających podjęciu decyzji nieprzemyślanej, pochopnej czy przypadkowej. Podmiotami ponoszącymi tę odpowiedzialność są członkowie rządu: Prezes Rady Ministrów, wiceprezesi, ministrowie - resortowi i bez teki, a także przewodniczący określonych w ustawie komitetów wchodzących w skład Rady Ministrów. Tym samym odpowiedzialność ponoszą wszyscy członkowie organu bez względu na zajmowane stanowisko, w równym stopniu. Przedmiotem odpowiedzialności solidarnej są wszelkie działania Rady Ministrów, a więc podejmowane zarówno na posiedzeniach, jak i przez organy wewnętrzne oraz Prezesa i członków rządu podejmowane w imieniu Rady Ministrów ${ }^{19}$. Powodem pociągnięcia organu wykonawczego do odpowiedzialności jest negatywna ocena prowadzonej przez niego polityki przez organ ustawodawczy. Niestety, zazwyczaj kryterium oceny ma charakter polityczny ${ }^{20}$. Procedurę egzekwowania odpowiedzialności politycznej Rady Ministrów w postaci konstruktywnego wotum nieufności inicjuje wniosek złożony przez grupę co najmniej 46 posłów, który musi wskazywać imiennie kandydata na Prezesa Rady Ministrów. Marszałek Sejmu, do którego wpływa wniosek nie został zobowiązany na podstawie przepisów do przeprowadzenia jego wstępnej kontroli. Jednak słusznie podnosi się w doktrynie, że Marszałek Sejmu powinien zweryfikować, czy zgłoszony wniosek „nie jest wadliwy, a więc przede wszystkim czy został zgłoszony przez odpowiednią liczbę posłów i przez nich podpisany oraz czy wskazuje kandydata na nowego premiera" ${ }^{21}$. Problematyczna wydaje się kwestia, co się stanie, jeśli Marszałek dostrzeże braki - czy powinien taki wniosek zwrócić, czy wyznaczyć termin do uzupełnienia ${ }^{22}$.

Wniosek musi być zgłoszony przez co najmniej 46 posłów $^{23}$, co ma uniemożliwić wystąpienie $\mathrm{z}$ wnioskiem przez bardzo małe grupy polityczne ${ }^{24}$. Wymaga on formy pisemnej. Przepisy milczą w kwestii uzasadnienia. W literaturze wskazuje się, że wymóg taki ograniczałby uprawnienie Sejmu do egzekwowania odpowiedzialności ${ }^{25}$. Po złożeniu nie są możliwe żadne modyfikacje wniosku ${ }^{26}$. W treści

19 K. Leszczyńska, Rada Ministrów i administracja rządowa - władza wykonawcza, [w:] Z. Szeliga (red.), Organy władzy publicznej w świetle Konstytucji Rzeczypospolitej Polskiej z 2 kwietnia 1997 r., Lublin 2006, s. 119.

20 R. Mojak, Parlament a rząd..., s. 550.

21 W. Sokolewicz, Komentarz do art. 158, [w:] L. Garlicki (red). Konstytucja Rzeczypospolitej Polskiej. Komentarz, t. II, Warszawa 2001, uwaga 22, s. 38.

22 R. Mojak twierdzi, że braki powinny zostać usunięte przez wnioskodawców we wskazanym przez Marszałka terminie. R. Mojak, Parlament a rzq̨d..., s. 565.

23 Art. 158.1 Konstytucji RP.

24 W. Sokolewicz, Komentarz do art. 158, uwaga 19, s. 32; L. Garlicki, Rada Ministrów..., s. 163.

25 W Sokolewicz, Komentarz do art. 158, uwaga 19, s. 36.

26 Art. 115 ust. 2 Regulaminu Sejmu: „1. Wniosek o wyrażenie wotum nieufności Radzie Ministrów składa się w formie pisemnej na ręce Marszałka Sejmu. 2. Po złożeniu wniosku podpisy 
musi być wskazany imiennie kandydat na urząd Prezesa Rady Ministrów. Jest to integralna część wniosku oraz istota konstruktywnego wotum nieufności ${ }^{27}$. O zgłoszeniu wniosku Marszałek Sejmu zawiadamia niezwłocznie Prezydenta RP i Prezesa Rady Ministrów. Głosowanie nad wnioskiem może się odbyć najwcześniej po upływie 7 dni od jego złożenia, na najbliższym posiedzeniu Sejmu po upływie tego terminu, ale nie później niż na następnym posiedzeniu. Odroczenie terminu głosowania o 7 dni ma zapobiec ewentualnej emocjonalnej ocenie sytuacji, przemyśleniu wniosku ${ }^{28}$. Jeżeli zgłoszono więcej niż jeden wniosek o wyrażenie wotum nieufności, są one rozpatrywane łącznie, jednak poddanie ich pod głosowanie następuje oddzielnie według kolejności zgłoszenia.

Rozpatrzenie wniosku obejmuje wystąpienie wnioskodawców, dyskusje, w której mogą zabrać głos zapisani do głosu posłowie. W debacie nad wnioskiem o wyrażenie wotum nieufności Marszałek Sejmu, poza kolejnością mówców zapisanych do głosu, udziela głosu wyłącznie Prezesowi Rady Ministrów. Premierowi przysługuje także tzw. ostatnie słowo ${ }^{29}$. Obowiązujące przepisy nie przewidują wystąpienia kandydata na Prezesa Rady Ministrów. Oznacza to, że posłowie nie mają możliwości zapoznania się z programem nowego rządu. Kandydat może wprawdzie zabrać głos w trakcie debaty, ale wyłącznie, gdy jest posłem i w tej właśnie roli ${ }^{30}$. W związku z powyższym w nauce prawa konstytucyjnego pojawiły się postulaty nowelizacji przepisów tak, by posłowie mogli lepiej poznać kandydata i program nowego rządu ${ }^{31}$.

Głosowanie nad wnioskiem jest jawne. Uchwalenie wotum nieufności następuje większością ustawowej liczby posłów, tj. minimum 231 głosów. Jeżeli zgłoszono kilka wniosków, w których wskazano innych kandydatów na premiera, to wnioski głosowane są oddzielnie, według kolejności zgłoszenia, przy czym uchwalenie jednego czyni bezprzedmiotowym głosowanie kolejnego ${ }^{32}$.

Uchwalenie wotum nieufności skutkuje dymisją Rady Ministrów oraz zobowiązuje Prezydenta RP do powołania wskazanego Prezesa Rady Ministrów. Odrzucenie przez Sejm wniosku nie wywołuje skutków w sferze zmian w składzie rządu, podnosi się jednak, że oznacza to sukces polityczny premiera ${ }^{33}$.

posłów popierających wniosek nie mogą być wycofane, a także nie mogą być pod nim składane dalsze podpisy". Uchwała Sejmu Rzeczypospolitej Polskiej z dnia 30 lipca 1992 r. - Regulamin Sejmu Rzeczypospolitej Polskiej, M.P. z 2018 r., poz. 729.

27 S. Patyra, Konstruktywne wotum nieufności jako formuła tworzenia i dymisji Rady Ministrów, „Przegląd Sejmowy” 2001, nr 1 (42), s. 14.

28 L. Garlicki, Rada Ministrów..., s. 164

29 S. Patyra, Konstruktywne wotum nieufności..., s. 15.

30 Szerzej: ibidem.

31 Ibidem, s. 16.

32 P. Winczorek, Komentarz do Konstytucji Rzeczypospolitej Polskiej z dnia 2 kwietnia 1997 r., Warszawa 2008, s. 322.

33 L. Garlicki, Rada Ministrów..., s. 166 
Powtórny wniosek może być zgłoszony nie wcześniej niż po upływie 3 miesięcy od dnia zgłoszenia poprzedniego wniosku. Wniosek może być zgłoszony przed upływem 3 miesięcy, jeżeli wystąpi z nim co najmniej 115 posłów (art. 158 ust 2 Konstytucji RP). Przyjąć należy, że wymogi te dotyczą każdego kolejnego wniosku $^{34}$, choć niektórzy przedstawiciele doktryny podnoszą, że ograniczenie to dotyczy wyłącznie wniosku, w którym wskazany jest ten sam kandydat na premiera. Sugerują oni, że jeśli posłowie wskażą inną osobę, wówczas nie ma konieczności uzyskania poparcia 115 posłów lub oczekiwania aż 3 miesiące ${ }^{35}$.

Procedura uchwalenia konstruktywnego wotum nieufności stwarza barierę dla jej wykorzystywania ${ }^{36}$. Podnosi się, że „zwiększa niespójność rozwiązań systemowych [...] zwłaszcza w zakresie koncepcji systemów rządów" ${ }^{\prime 37}$. Należy zwrócić uwagę, że ta forma odpowiedzialności została powiązana $\mathrm{z}$ odpowiedzialnością Prezesa Rady Ministrów, co jest związane z jego statusem jako premiera ${ }^{38}$. Konstruktywne wotum nieufności w kompleksowej ocenie należy uznać za środek nakierowany na zmuszenie rządu do ustąpienia ${ }^{39}$.

Poza konstruktywnym wotum nieufności wobec Rady Ministrów i premiera ustrojodawca przewidział także indywidualne wotum nieufności wobec członków rządu. Zakres podmiotowy obejmuje wszystkich członków Rady Ministrów poza premierem $^{40}$. Odpowiedzialność Prezesa Rady Ministrów wyczerpuje się w konstruktywnym wotum nieufności - solidarnej odpowiedzialności członków Rady Ministrów. Wniosek o wyrażenie wotum nieufności może być zgłoszony przez co najmniej 69 posłów (art. 159 Konstytucji RP). Do zakresu przedmiotowego odpowiedzialności indywidualnej należy ocena wykonania kompetencji ministra, a także powierzonych mu przez premiera zadań. Ponadto ponosi on odpowiedzialność także za realizację obowiązków osób podlegających mu jako ministrowi ${ }^{41}$. Wymóg poparcia wyższy niż dla konstruktywnego wotum nieufności spotyka się z krytyką niektórych przedstawicieli doktryny ${ }^{42}$. Procedura zgłoszenia oraz rozpatrzenia wniosku jest tożsama z przewidzianą $\mathrm{w}$ przypadku wniosku o wyrażenie wotum

34 S. Patyra, Konstruktywne wotum nieufności..., s. 17.

35 W. Sokolewicz, Komentarz do art. 158, s. 34.

36 W czasie obecnej kadencji parlamentu wniosek o wyrażenie wotum nieufności Radzie Ministrów kierowanej przez Prezes Rady Ministrów Beatę Szydło i wybranie Grzegorza Schetyny na Prezesa Rady Ministrów złożony został 24 marca 2017 r. (druk sejmowy nr 1436). Wniosek złożony przez posłów Platformy Obywatelskiej o wyrażenie rządowi Beaty Szydło wotum nieufności został odrzucony. Głosowało 416 posłów. Większość ustawowa wynosiła 231 posłów. Za było 174 posłów, przeciw 238 posłów (http://www.tvn24.pl, dostęp: 6.06.2018).

37 E. Gdulewicz, R. Mojak, Rola ustrojowa i struktura organizacyjna Rady Ministrów, [w:] W. Skrzydto (red.), Ustrój i struktura aparatu państwowego..., s. 153.

38 W. Sokolewicz, Komentarz do art. 158, uwaga 9, s. 14.

39 M. Grzybowski et al., Prawo konstytucyjne, Białystok 2008, s. 283.

40 L. Garlicki, Rada Ministrów..., s. 169; W. Sokolewicz, Komentarz do art. 158, uwagi 4-9, s. 6 i n.

41 W. Skrzydło, Ustrój polityczny RP w świetle Konstytucji z 1997 r., Kraków 1998, s. 196.

42 R. Mojak, Parlament a rzq̨d..., s. 586; L. Garlicki, Rada Ministrów..., s. 170. 
nieufności dla rządu, z tą różnicą, że w debacie nad wnioskiem o wyrażenie ministrowi wotum nieufności Marszałek Sejmu, poza kolejnością mówców zapisanych do głosu, udziela głosu wyłącznie Prezesowi Rady Ministrów oraz ministrowi, którego wniosek dotyczy. Ponadto podczas debaty nad wnioskiem przedstawiana jest opinia jednej lub kilku komisji sejmowych.

Wniosek jest uchwalony większością ustawowej liczby posłów. Jeśli Sejm uchwali wotum nieufności, wówczas Prezydent Rzeczypospolitej odwołuje go z zajmowanego stanowiska. Nieuchwalenie nie wywołuje zaś żadnych skutków prawnych. Podobnie jak w przypadku wniosku o wotum nieufności dla rządu, kolejny wniosek dotyczący członka rządu nie może być zgłoszony przed upływem 3 miesięcy od dnia zgłoszenia poprzedniego, chyba że wystąpi z nim co najmniej 115 posłów.

Problem uzupełniania solidarnej odpowiedzialności rządu przez indywidualną odpowiedzialność jego członków był przedmiotem zarówno sporów w trakcie prac Komisji Konstytucyjnej, jak i ożywionej dyskusji w doktrynie. Krytycy tego rozwiązania zwracają uwagę, że indywidualna odpowiedzialność ministrów wobec Sejmu jest niespójna z polską wersją systemu rządów. Osłabia ona zależność ministrów od premiera, ułatwia działania opozycji parlamentarnej ${ }^{43}$. Jednak praktyka dowodzi, że odpowiedzialność polityczna rządu i jego członków, aby była skuteczna, musi być realna - możliwa do zastosowania. W czasie obecnej, VIII kadencji Sejmu (pierwsze posiedzenie odbyło się w listopadzie 2015 r.) wniosek złożony był raz, w 2017 r., i był nieskuteczny ${ }^{44}$. Podobnie rzecz się ma z indywidualnym wotum nieufności - dotychczas złożono 10 wniosków i wszystkie zostały przegłosowane przez koalicję rządzącą ${ }^{45}$.

43 A. Bałaban (red.), Rada Ministrów - organizacja..., s. 167.

44 Wniosek o wyrażenie konstruktywnego wotum nieufności Radzie Ministrów kierowanej przez Prezes Rady Ministrów Beatę Szydło i wybranie Grzegorza Schetyny na Prezesa Rady Ministrów (druk sejmowy nr 1436), kwiecień 2017.

45 Wniosek o wyrażenie wotum nieufności wobec ministra spraw wewnętrznych i administracji Mariusza Błaszczaka (druki sejmowe nr 281 i 297), marzec 2016; Wniosek o wyrażenie wotum nieufności wobec ministra obrony narodowej Antoniego Macierewicza (druki sejmowe nr 1520 i 1556), lipiec 2016; Wniosek o wyrażenie wotum nieufności wobec minister edukacji narodowej Anny Zalewskiej (druki sejmowe nr 934 i 967), listopad 2016; Wniosek o wyrażenie wotum nieufności wobec ministra środowiska Jana Szyszko (druki sejmowe nr 1320 i 1336), marzec 2017; Wniosek o wyrażenie wotum nieufności wobec ministra obrony narodowej Antoniego Macierewicza (druki sejmowe nr 662 i 677), maj 2017; Wniosek o wyrażenie wotum nieufności wobec ministra spraw wewnętrznych i administracji Mariusza Błaszczaka (druki sejmowe nr 1629 i 1681), lipiec 2017; Wniosek o wyrażenie wotum nieufności wobec ministra rolnictwa i rozwoju wsi Krzysztofa Jurgiela (druki sejmowe nr 1838 i 1842), wrzesień 2017; Wniosek o wyrażenie wotum nieufności wobec ministra kultury i dziedzictwa narodowego Piotra Glińskiego (druki sejmowe nr 2478 i 2492), maj 2018; Wniosek o wyrażenie wotum nieufności wobec wiceprezes Rady Ministrów, przewodniczącej Komitetu Społecznego Rady Ministrów Beaty Szydło (druki sejmowe nr 2495 i 2568), czerwiec 2018; Wniosek o wyrażenie wotum nieufności wobec minister rodziny, pracy i polityki społecznej Elżbiety Rafalskiej 
Odrębną instytucją mogącą służyć egzekwowaniu odpowiedzialności jest wotum zaufania. Jest to uchwała parlamentu wyrażająca poparcie dla działalności rządu, która podejmowana jest na wniosek Rady Ministrów lub premiera. Uchwała parlamentu wywołuje skutki w sferze politycznej i prawnej. W pierwszym przypadku służy wzmocnieniu legitymacji politycznej lub odnowieniu przez rząd inwestytury politycznej ${ }^{46}$. Wotum zaufania może też stanowić „formę swoistej gry parlamentarnej rządu z Sejmem" ${ }^{\prime 7}$. Zgodnie z art. 160 Konstytucji RP Prezes Rady Ministrów może zwrócić się do Sejmu o wyrażenie Radzie Ministrów wotum zaufania. Izba podejmuje decyzję większością głosów w obecności co najmniej połowy ustawowej liczby posłów. Dotychczas, ilekroć taki wniosek był zgłaszany, każdorazowo głosowanie było pozytywne dla rządu ${ }^{48}$.

Scharakteryzowane powyżej instytucje służące egzekwowaniu odpowiedzialności parlamentarnej Rady Ministrów dowodzą, że niestety, to nie regulacje przesądzają o skuteczności tej formy odpowiedzialności, lecz praktyka polityczna - dowodzi ona, że w przypadku stabilnej większości w parlamencie ta forma jest nieskuteczna.

\section{Santrauka}

\section{Politinè Ministrų Tarybos atsakomybè}

Remiantis konstitucine teise, išskiriame dvi atsakomybès rūšis: politinę (parlamentinę) ir teisinę (konstitucinę). Šio tyrimo tema lieka vien politinè atsakomybè, kurią siaurai reglamentuoja Ministrų Taryba. Visuotinai pripažistama, kad valdžios institucijų atsakomybe yra vienas iš pagrindinių šiuolaikinių demokratijų reikalavimų. Tai yra demokratijos mechanizmų, naudojančių valdžią, dalis ir yra teisinès valstybès garantija, todèl analizuojamos problemos yra labai svarbus tyrimo dalykas.

Lenkijos vyriausybès politinès atsakomybès pavyzdžiu pabrè̌iama, kad ji yra parlamentinio pobūdžio, nes Ministrų Taryba prisiima šią atsakomybę prieš Seimą; racionalizuota, nes dèl jos veiksmingumo reikia užbaigti sudètingas procedūrines ir konstitucines sąlygas, kadangi sisteminio pobūdžio svarstymai lemia politinị parlamentinès

(druki sejmowe nr 2496 i 2569), czerwiec 2018; Wniosek o wrażenie wotum nieufności wobec minister edukacji narodowej Anny Zalewskiej (druk sejmowy nr 2850), wrzesień 2018.

46 E. Gdulewicz, R. Mojak, Rola ustrojowa i struktura organizacyjna Rady Ministrów..., s. 154; R. Mojak, Parlament a rząd..., s. 574.

47 R. Mojak, Parlament a rzq̨d..., s. 575.

4813 czerwca 2003 r. (na wniosek Leszka Millera); 15 października 2004 r. (na wniosek Marka Belki); 12 października 2012 r. (na wniosek Donalda Tuska); 25 czerwca 2014 r. (na wniosek Donalda Tuska, po raz drugi). 
atsakomybės pobūdị. Vadovaujantis Lenkijos Respublikos Konstitucijos nuostatomis, Ministrų Taryba prisiima atsakomybę Seime, o ne Senate, jau nekalbant apie Lenkijos Respublikos Prezidentą. Tokios konstrukcijos pagrindimas yra Seimo kontrolès funkcijos igyvendinimas. Parlamento atsakomybè yra ịtvirtinta bendros ir individualios atsakomybès procedūroje. Pirmoji iš jų buvo išreikšta konstruktyviu balsavimu dèl nepasitikejjimo. Ši institucija yra formalizuota ir joje yra keli reikalavimai, siekiant išvengti neapgalvotų, skubotų ar atsitiktinių sprendimų. Šios atsakomybės subjektai yra visi Ministrų Tarybos nariai, vienodai atsakingi nepriklausomai nuo jų padèties. Tema yra visi vyriausybès veiksmai, vykdomi Ministrų Tarybos vardu. Prièmus nepasitikejjimo pareiškimą, atsistatydina Ministrų Taryba, ir ịpareigoja Lenkijos Respublikos Prezidentą paskirti Ministrų Tarybos pirmininką. Pareiškimo atmetimas Seime neturi įtakos vyriausybès sudėties pokyčiams, tačiau sakoma, kad tai reiškia politinę ministro pirmininko sèkmę. Individualaus skundo subjektyvioji taikymo sritis apima visus Ministrų Tarybos narius, išskyrus premjerą. Paraiškos pateikimo procedūra ir prašymo nagrinejjimas yra tokie patys kaip ir pirmuoju atveju. Konstitucinio komiteto darbe ir doktrinos gyvoje diskusijoje, kuri iki šiol vyksta, buvo ginčai, susiję su problema papildyti solidariąją vyriausybès atsakomybę už jos narių individualią atsakomybę. Praktika vis dèlto įrodo, tam kad vyriausybès ir jos narių politinè atsakomybẻ būtų veiksminga, ji turi būti reali - galimai pritaikoma veikloje.

\section{Literatura}

Banaszak B., Prawo konstytucyjne, Warszawa 1999.

Banaszak B., Trybunał Stanu - stagnacja czy zmiany, „Zeszyty Naukowe Sądownictwa Administracyjnego" 2008, nr 1.

Berek M., Konstytucyjne ramy wykonywania przez Prezesa Rady Ministrów funkcji przewodniczacego kolegialnego organu władzy publicznej, [w:] E. Gdulewicz, W. Orłowski, S. Patyra (red.), 25 lat transformacji ustrojowej $w$ Polsce $i w$ Europie Środkowo-Wschodniej, Lublin 2015.

Braud Ph., Rozkosze demokracji, Warszawa 1995.

Cybichowski Z., Polskie prawo państwowe na tle uwag z dziedziny nauki o państwie i porównawczego prawa państwowego III, Warszawa 1929.

Domagała M., Charakter prawny i miejsce Trybunału Konstytucyjnego i Trybunału Stanu w systemie organów państwa, [w:] W. Skrzydło (red.), Ustrój i struktura aparatu państwowego i samorzadu terytorialnego, Warszawa 1997.

Dudek D., Zakres podmiotowy odpowiedzialności członków rzq̨du, [w:] M. Safjan, L. Bosek (red.), Konstytucja. Komentarz, t. II, Warszawa 2016.

Działocha K., Zalasiński T., Trybunał Stanu, [w:] L. Garlicki (red.), Konstytucja Rzeczypospolitej Polskiej. Komentarz, t. IV, Warszawa 2007. 
Dziemidok-Olszewska B., Odpowiedzialność głowy państwa i rządu we wspótczesnych państwach europejskich, Lublin 2012.

Eckhardt K., Problem regulacji zakresu podmiotowego odpowiedzialności konstytucyjnej - uwagi porządkujace, [w:] M. Grzybowski, P. Tuleja, Państwo demokratyczne, prawne i socjalne. Studia konstytucyjne. Tom I. Ksiega jubileuszowa dedykowana Profesorowi Zbigniewowi Antoniemu Maciągowi, Kraków 2014.

Esmein A., Prawo konstytucyjne, Warszawa 1921.

Frankiewicz A., Kontrasygnata aktów urzędowych Prezydenta RP, Kraków 2004.

Garlicki L., Rada Ministrów: powoływanie - kontrola - odpowiedzialność, [w:] A. Bałaban (red.), Rada Ministrów - organizacja i funkcjonowanie, Kraków 2002.

Grajewski J., Warunki ustawowe i wymogi formalne wstępnego wniosku o pociagnięcie do odpowiedzialności konstytucyjnej przed Trybunałem Stanu, „Przegląd Sejmowy” 2000, nr 1.

Granat M., Normatywny model odpowiedzialności konstytucyjnej w praktyce, [w:] W. Skrzydło (red.), Sady i trybunały w konstytucji i w praktyce, Warszawa 2005.

Gromek Z., Odpowiedzialność konstytucyjna a kontrola sejmowa. Wybrane zagadnienia, „Przegląd Sejmowy” 2008, nr 3.

Gromek Z., Odpowiedzialność konstytucyjna z perspektywy dotychczasowych doświadczeń - wybrane zagadnienia, „Przegląd Legislacyjny” 2010, nr 3.

Grzybowski M., Bożyk S., Jackiewicz A., Kryszeń G., Matwiejuk J., Olechno A., Prokop K., Prawo konstytucyjne, Białystok 2008.

Hudzik J., Rozum - wolność - odpowiedzialność. Studium z historii idei w nowożytnej i współczesnej myśli filozoficznej, Lublin 2001.

Kmiecik R., Opinia prawna o możliwości wszczęcia postępowania w zakresie odpowiedzialności konstytucyjnej wobec członka organu kolegialnego (na przykładzie KRRiTV), [w:] M. Królikowski, W. Odrowąż-Sypniewski (red.), Studia Biura Analiz Sejmowych Kancelarii Sejmu. Postępowanie przed Komisja Odpowiedzialności Konstytucyjnej. Zagadnienia Systemowe, Warszawa 2007.

Komarnicki W., Polskie prawo polityczne (geneza i system), Warszawa 1922.

Kowalska M., Polityczny wymiar odpowiedzialności konstytucyjnej członków Rady Ministrów, „Annales Universitatis Mariae Curie-Skłodowska. Sectio K” 2003, vol. X.

Kowalska M., Szeliga Z., Sejmowa kontrola działalności rządu oraz odpowiedzialność rządu przed Sejmem, [w:] M. Żmigrodzki (red.), Polityczno-prawne aspekty transformacji systemowej $w$ Polsce, Lublin 2000.

Krawczyk R. P., Trybunat Stanu - odpowiedzialność konstytucyjna, [w:] T. Szymczak (red.), Prawo konstytucyjne (wybrane zagadnienia), Łódź 1996.

Kręcisz W., Glosa do wyroku Sądu Najwyższego z dnia 6 stycznia 1999 r. (sygn. akt III RN 108/98), „Przegląd Sejmowy” 1999, nr 4.

Krukowski S., Konstytucja Rzeczypospolitej Polskiej z 1921 r., [w:] M. Kallas (red.), Konstytucje Polski. Studia monograficzne z dziejów polskiego konstytucjonalizmu 2, Warszawa 1990.

Kuca G., Zasada podziału władzy w Konstytucji RP, Warszawa 2014. 
Kuciński J., Legislatywa, egzekutywa, judykatywa. Konstytucyjne instytucje i mechanizmy służące równowadze władz w polskim systemie trójpodziału, Warszawa 2010.

Laskowska M., Sokolewicz W., Odpowiedzialność członków Rady Ministrów w Konstytucji RP na tle porównawczym, „Zeszyty Naukowe Wyższej Szkoły Handlu i Prawa im. Ryszarda Łazarskiego w Warszawie. Prawo" 2002, z. 6.

Leszczyńska K., Rada Ministrów i administracja rządowa - władza wykonawcza, [w:] Z. Szeliga (red.), Organy władzy publicznej w świetle Konstytucji Rzeczypospolitej Polskiej z 2 kwietnia 1997 r., Lublin 2006.

Łazarski K., Power Tends to Corrupt: Lord Acton's Study of Liberty, DeKalb 2012.

Mojak R., Odpowiedzialność prawna członków Rady Ministrów w świetle Konstytucji RP z 2 kwietnia 1997 r., „Zeszyty Naukowe Akademii Podlaskiej w Siedlcach. Administracja i Zarządzanie" 2009, nr 82.

Mojak R., Odpowiedzialność prawna posłów i senatorów przed Trybunałem Stanu w świetle Konstytucji RP z 2 kwietnia 1997r., [w:] R. M. Czarny, K. Spryszak (red.), Państwo i prawo wobec współczesnych wyzwań. Zagadnienia prawa konstytucyjnego. Ksiega jubileuszowa Profesora Jerzego Jaskierni, Torun 2012.

Mojak R., Parlament a rząd w ustroju Trzeciej Rzeczypospolitej Polskiej, Lublin 2007.

Mojak R., Status ustrojowy Rady Ministrów, [w:] W. Skrzydło, R. Mojak (red.), Ustrój polityczny Rzeczypospolitej Polskiej w nowej Konstytucji z 2 kwietnia 1997 r., Lublin 1998.

Montesquieu K. L., O duchu praw, t. 1, Warszawa 1957.

Mordwiłko J., Nowe uregulowania prawa konstytucyjnego w okresie 1980-1985, Warszawa 1986

Odrowąż-Sypniewski W., Odpowiedzialność konstytucyjna członków organów kolegialnych, [w:] M. Królikowski, W. Odrowąż-Sypniewski (red)., Studia Biura Analiz Sejmowych Kancelarii Sejmu. Postępowanie przed Komisją Odpowiedzialności Konstytucyjnej. Zagadnienia systemowe, Warszawa 2007.

Odrowąż-Sypniewski W., Odpowiedzialność konstytucyjna członków organów kolegialnych, „Przegląd Sejmowy” 2006, nr 6.

Opaliński B., Kontrasygnata aktów głowy państwa w polskim konstytucjonalizmie. Kontrasygnata w Konstytucji Rzeczypospolitej Polskiej z 2 kwietnia 1997 r. Część II, „Ius Novum" 2011, nr 3.

Opaliński B., Udział Prezydenta RP $w$ kształtowaniu składu Rady Ministrów w Konstytucji Rzeczypospolitej Polskiej z 1997 roku, Toruń 2013.

Patyra S., Konstruktywne wotum nieufności jako formuła tworzenia i dymisji Rady Ministrów, „Przegląd Sejmowy” 2001, nr 1 (42).

Patyra S., Prawnoustrojowy status Prezesa Rady Ministrów w świetle Konstytucji z 2 kwietnia 1997 r., Warszawa 2002.

Pietrzak M., Demokratyczne świeckie państwo prawne, Warszawa 1999.

Pietrzak M., Odpowiedzialność konstytucyjna w Polsce, Warszawa 1992.

Pietrzak M., Odpowiedzialność konstytucyjna, [w:] L. Garlicki (red.), Studia konstytucyjne, t. 5: Organy ochrony prawa - regulacja w nowej Konstytucji, Warszawa 1989. 
Piotrowski R., Kontrasygnata - uwagi o znaczeniu praktyki konstytucyjnej, „Zagadnienia Sądownictwa Konstytucyjnego" 2012, nr 2.

Pytlik B., Naczelne organy władzy w projektach Konstytucji III Rzeczypospolitej Polskiej. Struktura i odnawianie składu, Warszawa 2005.

Rakowska A., Kontrasygnata aktów głowy państwa w wybranych państwach europejskich, Toruń 2009.

Sakowicz A., Steinborn S., Trybunał Stanu, [w:] M. Safjan, L. Bosek (red.), Konstytucja. Komentarz, t. II, Warszawa 2016.

Sarnecki P., Komentarz do art. 145, [w:] L. Garlicki (red.), Konstytucja Rzeczypospolitej Polskiej. Komentarz, t. I, Warszawa 1999.

Sarnecki P., Ustrojowa pozycja Prezesa Rady Ministrów w polskich aktach konstytucyjnych, [w:] P. Radziewicz, J. Wawrzyniak (red.), Konstytucja, rząd, parlament. Ksiega jubileuszowa Profesora Jerzego Ciemniewskiego, Warszawa 2014.

Seidler G. L., Odpowiedzialność parlamentarna a konstytucyjna, „Państwo i Prawo” 1989, nr 12.

Siemieński F., Odpowiedzialność konstytucyjna członka rządu w świetle art. 41 Konstytucji $R P$, „Dziś” 1992, nr 3.

Siemieński F., Odpowiedzialność konstytucyjna osób pełniących najwyższe stanowiska państwowe w Polsce, [w:] L. Antonowicz, W. Skrzydło, W. Śladkowski, J. Ziembiński, M. Granat, Wybrane problemy prawa konstytucyjnego, Lublin 1985.

Skrzydło W., Gdulewicz E., Granat M., Koksanowicz G., Kręcisz W., Mojak R., Orłowski W., Patyra S., Sadowski P., Sobczak J., Zakrzewski W., Polskie prawo konstytucyjne, Lublin 2010.

Smith G., Życie polityczne w Europie Zachodniej, Warszawa 1992.

Sokolewicz W., Komentarz do art. 158, [w:] L. Garlicki (red.), Konstytucja Rzeczypospolitej Polskiej. Komentarz, t. II, Warszawa 2001.

Sokolewicz W., Odpowiedzialność parlamentarna Rządu RP, Warszawa 1993.

Szeliga Z., Rada Ministrów a Sejm, Lublin 1998.

Wajda D., Uwagi o potrzebie reformy Trybunału Stanu, „Przegląd Sejmowy” 2008, nr 2.

Wasilewski A., Uwagi na marginesie glosy Pana Wojciecha Kręcisza, „Przegląd Sejmowy” 2000, nr 2.

Wiatr J., Odpowiedzialność konstytucyjna w teorii i praktyce III Rzeczypospolitej, „Europejski Przegląd Prawa i Stosunków Międzynarodowych” 2009, nr 3-4.

Wilga W., Powstanie i ewolucja instytucji kontrasygnaty, „Przegląd Sejmowy” 1996, nr 4.

Wiliński P., Wszczęcie postępowania w przedmiocie odpowiedzialności konstytucyjnej członka organu kolegialnego, [w:] M. Królikowski, W. Odrowąż-Sypniewski (red.), Postępowanie przed Komisją Odpowiedzialności Konstytucyjnej. Zagadnienia Systemowe, Studia Biura Analiz Sejmowych Kancelarii Sejmu, Warszawa 2007.

Winczorek P., Komentarz do Konstytucji Rzeczypospolitej Polskiej z dnia 2 kwietnia 1997 r., Warszawa 2008.

Wójtowicz K., Zasady i praktyka funkcjonowania odpowiedzialności konstytucyjnej w innych państwach, [w:] Z. Świda-Łagiewska (red.), Trybunał Stanu w PRL, Warszawa 1983. 
Zaleśny J., Konstytucyjne koncepcje odpowiedzialności, [w:] M. Kruk (red.), Konstytucja RP z 1997 r. na tle zasad współczesnego państwa prawnego. Zagadnienia wybrane, Warszawa 2006.

Zaleśny J., Odpowiedzialność konstytucyjna w prawie polskim okresu transformacji, Toruń 2004. Zaleśny J., Odpowiedzialność konstytucyjna. Praktyka III RP, Warszawa 2004.

Zrębiec D., Zakres podmiotowy i przedmiotowy odpowiedzialności konstytucyjnej w nowej Konstytucji RP (wybrane zagadnienia), „Annales Universitatis Mariae Curie-Skłodowska. Sectio G” 1999, vol. XLVI.

\section{Druki sejmowe}

Druk sejmowy nr 281

Druk sejmowy nr 297

Druk sejmowy nr 662

Druk sejmowy nr 677

Druk sejmowy nr 934

Druk sejmowy nr 967

Druk sejmowy nr 1320

Druk sejmowy nr 1336

Druk sejmowy nr 1436

Druk sejmowy nr 1520

Druk sejmowy nr 1556

Druk sejmowy nr 1629

Druk sejmowy nr 1681

Druk sejmowy nr 1838

Druk sejmowy nr 1842

Druk sejmowy nr 2478

Druk sejmowy nr 2492

Druk sejmowy nr 2495

Druk sejmowy nr 2496

Druk sejmowy nr 2568

Druk sejmowy nr 2569

Druk sejmowy nr 2850

\section{Akty prawne}

Konstytucja Rzeczypospolitej Polskiej z dnia 2 kwietnia 1997 r., Dz.U. z 1997 r., nr 78, poz. 483.

Uchwała Sejmu z dnia 30 lipca 1992 r. - Regulamin Sejmu Rzeczypospolitej Polskiej, M.P. z 2018 r., poz. 729.

\section{Strony internetowe}

http://www.tvn24.pl (dostęp: 6.06.2018). 